\title{
Gulliver in the Land of Giants? The Opportunities of the Hungarian Initiations in the Surgical Medical Touristic Market*
}

\author{
Ivett Sziva \\ Budapest College of Communication and Business, Budapest, Hungary
}

\begin{abstract}
Medical tourism seems to be one of the most dynamically growing segments of health tourism; what is more, it is evaluated as a "wonder-niche" product by the rest of the destinations in trouble because of the economic downturn. However, lots we hear about the area called medical or surgical or clinical or health-related tourism, the definitions are not clear, nor the measurement of the volume. Moreover, there are several challenging questions regarding quality factors of services, management of the seamless process of care, and liability issues in the area. There are two main aims of the paper: (1) to give an academic perspective, which might be useful for the practice about the most challenging questions of surgical medical tourism, like definition, dimensions of competition, and service process management; and (2) to map the Hungarian surgical medical touristic market in the framework of an exploratory research based on a content analysis and experts' interviews in order to give recommendations for the development.
\end{abstract}

Keywords: health tourism, medical tourism, private clinic, public hospital, Hungary, Central-Eastern Europe

\section{Introduction}

The phenomenon of traveling abroad for medical treatments is not new, as wealthy patients from less-developed countries traveled for cure to European and American clinics even in the 19th century. Nowadays, the flow of medical tourism became more complex. The success stories of the top Asian destinations show enormous change in the supply side and raise the question of the changes affecting the demand side as well.

Firstly, the paper focuses on the definitional issues, so as to define health, medical, and medical surgical tourism. Secondly, the key dimensions of competition are analyzed, particularly in the Central and Eastern Europe market (focusing on the emerging market of Romania, Bulgaria as well) in order to map the success factors of medical tourism market. The aim of the paper is to analyze the definitional issues with regard to Central-Eastern Europe and particularly Hungary, based on the international definitions, and to look at the success factors in order to give recommendations for further development.

\section{A Borderless Product?}

\section{Defining and Measuring Medical Tourism}

Medical tourism is a dynamically growing segment of health tourism, which commonly known as

\footnotetext{
* Acknowledgment: The author would like to express sincere appreciation for the support of the project KTIA_AIK_12-1-2013-004, from Research and Technology Innovation Fund (Kutatási és Technológiai Innovációs Alap).

Ivett Sziva, Ph.D., senior professor, Institute of Tourism and Catering, Budapest College of Communication and Business. Email: isziva@bkf.hu; ivett.sziva@gmail.com.
} 
including all the forms of traveling for cure and prevention. Among the driving forces of medical tourism, nowadays we can find the overburdened health-care systems, "graying" societies and celebrity culture or differences in technology and prices, and last but not least, the blurring in health touristic services and the need for holistic services.

There are a lot of debates regarding the definition of medical tourism, about what a deep analysis can be found in Connell (2012). It is really important to make a difference between the motivational factors (medical tourism could be first or additional motivation of the trip), while it is also difficult to define what a medical treatment is (Cook, Kendall, Michael, \& Brown, 2013). Hall (2013) enhanced that medical tourism is about curing illnesses, though it could also be questioned whether the tourist travelling for cosmetic surgery is ill or not.

Health tourism can be divided into two parts: wellness and medical tourism. Medical tourism could be further decomposed: Smith and Puczkó (2008) have broken medical tourism down into therapeutic tourism (based on natural healing resources) and surgical tourism (mostly traditional Western medicine is used). They pointed out an important trend of the holistic concept of wellness, which gains ground in every area of health tourism. The commonly known definition of medical tourism relates to the surgical tourism defined above, as the point of these overall definitions is: traveling to abroad to obtain medical services as dental and surgical care (Deloitte, 2009; Organization for Economic Cooperation and Development [OECD], 2009), but complex packages can be made with alternative treatments based on natural resources (Health Care Research Centre [ESKI], 2009; Youngman, 2009, 2012). Medical Tourism Association (2013) gave an overall definition:

People who live in one country travel to another country or travel within their country to receive medical, dental, and surgical care while at the same time receiving equal to or greater care than they would have in their own country, and are travelling for medical care because of affordability, better access to care, or a higher level of quality of care. (p. 1)

Defining surgical tourism in details is important regarding the confusion of statistics: While some of the experts estimate that 10 million travelers seek for cure abroad, other studies (McKinsey, 2008) restrict this amount to 85 thousand worldwide. One of the official statistics in the area is that of OECD (2009), which is based on the balance of payments item called "health-related travel", which also includes the medical trips with the first motivation of curing and spa travel. According to these official statistics, the United States of America (USA) is the largest exporter of health-related services (2.3 billion USD in 2007), followed by Turkey (489 million USD), the Czech Republic (481 million USD), Belgium (348 million USD), Mexico (311 million USD), Italy (218 million USD), and Hungary (211 million USD). Among the greatest importers (source markets), we face Germany, USA, the Netherlands, Canada, Belgium, and Austria. The main question behind the statistics is who can be considered as medical tourists and how to measure their flow. Taking the exact definition of McKinsey (2008) as a starting point, and looking into the criticism of that (Youngman, 2009) summarized in Table 1, the following definition could be given, based on the general definition of tourism (travel lasting more than 24 hours, but less than one year, including touristic services), and taking a stand on the debate.

Medical trips to abroad with the voluntary (main or part) motivation of obtaining medical health services based on particularly Western medicine, which might include alternative healing methods as well as outpatient surgeries, but exclude treatments for expatriates and emergency cases. As the commonly known medical tourism definition overlaps or equals to that of surgical tourism, the terms will be used as synonyms in the following. 
Table 1

The Characteristics and the Dimensions of Medical Tourism

\begin{tabular}{|l|l|l|}
\hline Dimension & Statement (McKinsey) & Evaluation (Youngman) \\
\hline Length of stay in hospital & Only inpatients & Both inpatients and outpatients \\
\hline Main motivation & Only medical & Mixed motivations \\
\hline Emergency included & No emergency & No emergency \\
\hline Expatriates included & No expatriates & No expatriates \\
\hline Trip to neighboring countries & Excluded & Included \\
\hline Type of treatments & Western medicine & Holistic view, alternative methods inc. \\
\hline Estimated volume of the market & 85,000 worldwide & $\begin{array}{l}5 \text { million worldwide (America } 600 \text { ths., Europe } \\
1.75 \mathrm{~m} \text {, and Asia } 2.25 \mathrm{~m})\end{array}$ \\
\hline
\end{tabular}

\section{The Dimension of the Competition}

\section{The Features of the Medical Touristic Market}

Being medical tourism a promising niche-segment of tourism, newer destinations appear in the competition, mainly in the most popular outpatient surgeries area, at dental and cosmetic treatments. Among the commonly known medical hubs (e.g., Asian countries, USA, Spain, Belgium), other rising European destinations (Cyprus, the Czech Republic, Poland, Croatia, Bulgaria, and Hungary) should be analyzed to get a total picture. An analysis was carried out (summary can be seen in Appendix A) based on studies of Deloitte (2009), ESKI (2009), Medical Tourism Association (2009), as well as researching the web appearance of the destinations and having experts' interviews.

Four different segments can be created among the analyzed countries, particularly based on the factors of the prices, the know-how, and the volume of the market. The below expressed categories can be named as the development phases of medical tourism as well:

(1) Premium category based on high-level know-how: USA and Germany play in the first, premium category, where competition is fueled by innovation and high-tech, with high price level generally or in certain areas;

(2) Medium category with permanent patient flow and professional market behavior: Spain, Belgium, and Cyprus belong to the second middle segment, regarding prices and technology, where strong market ties and accreditation seem to be important. High volume of patients flow is assured by the professional seamless service;

(3) Countries with price advantage and industrialized medical tourism: Asian countries can be featured by "industrialized" medical tourism, which is due to the cost advantage and the powerful state subsidies (investments, marketing). The Asian countries use their traditional national healing methods for differentiation, which is an example to be followed;

(4) Countries with price advantage and bottom-up initiations: The Central European countries use out their cost advantages and the historic market contacts. It seems that isolated initiations are typical in these countries. Differentiation is really rare mostly in Central Europe, which can cause price competition in the future.

Among the main source markets of medical tourism, USA, Middle East, Germany, and the United Kingdom (UK) can be pointed out based on the estimations (McKinsey, 2008; Harryono, Huang, Miyazawa, \& Sethaput, 2006). In these countries, the main driving force is the overburdened healthcare system or business type insurance, excepting Middle East where the lack of the highly sophisticated technology is the 
main reason. Elective treatments seem to be the most popular products, but orthopedics and cardiology appear regularly. In addition to price conditions, the holiday programs of the chosen destination are crucial for the British and Americans. In Germany, the financing conditions of the insurance institutions seem to be essential, while Islamic patients have special cultural needs (e.g., alcohol-free medicines, ample rooms to receive lots of visitors). The summary of the features of the most significant source markets can be seen in Appendix B.

\section{The Quality and Management Issues}

There are only a few researches regarding how medical tourists make their traveling decisions and what quality actually means for them, but according to them, it can be stated that the touristic resources are almost as important for tourists as the quality of medical services (Crompton, 2008; McKinsey, 2008). All these factors are summarized in Table 2.

Table 2

The Main Factors of Medical Traveling Decision

\begin{tabular}{|l|l|}
\hline Medical factor & Touristic factor \\
\hline Reputation and skills of the doctors & Reputation as a touristic destination \\
\hline Results of the medical treatments & Price of the trip \\
\hline Price of the treatments & Developed infrastructure \\
\hline Insurance and guarantee & Cultural closeness \\
\hline Follow-up and supporting services & Safety and stability \\
\hline Foreign language skills & \\
\hline
\end{tabular}

Responding to the demands' requirements, the following steps are (or should be) taken by the medical service suppliers, based on the results of experts' researches (McKinsey, 2008; Johnson, 2010; Youngman, 2009) and guidelines of the American Medical Association (AMA, 2009):

(1) Transparency: Proper and honest information about the results (number of complications, unsuccessful cases), policy of guarantees is crucial information regarding traveling decisions;

(2) Quality control/accreditation: A debate lies in the question of accreditation: Some practitioners find it an unnecessary process, as price and reputation are the key issues, others think that it is really important regarding marketing and operation effectiveness;

(3) International network/seamless services: The key issue regarding medical trips is to assure the feeling of permanent safety, care, and well-being, so highly personalized services (transfer, hostess, assistance services, and interpreter) are essential. The greatest challenge is to solve the pre-travel and the follow-up services in the mother country, and the opinion of the Hungarian medical facilitator will be expressed in Section 4. It can be seen that managing the seamless process needs professional facilitators, though the process of des-intermediation appeared in medical tourism as well, due to the internet;

(4) Insurance: Having long-run contacts with the private or public insurance companies seems to be a driving factor of the success. In the USA, several insurance companies started to introduce mini-mad plans for overseas healthcare. There are governmental initiations in the UK as well as in Germany to finance publicly those treatments abroad, which are unsolvable at home. In the European Union (EU), steps are taken to ease the process of patients' mobility, so that the EU citizens could obtain publicly financed treatments in another EU country. Insurance is an important question regarding liability issues: There is a shortage in travel insurance including medical services. 
Figure 1 summarizes the factors influencing the success and the players of medical tourism, highlighting destination management organizations (DMOs) and the institutions for cooperation (IFCs, e.g., chambers, research institutions).

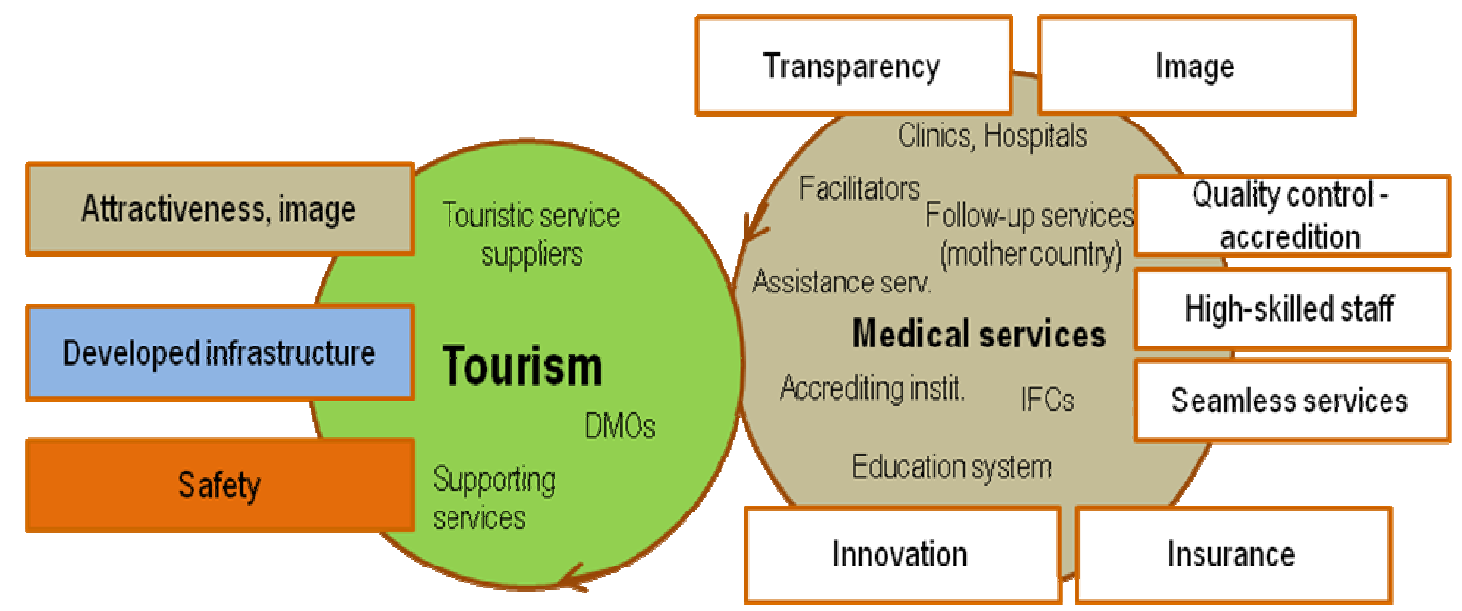

Figure 1. The main factors of quality and management of medical tourism.

\section{Case Study of Hungary}

Hungary can be called as the "silent Gulliver" of the medical touristic market, as the country makes a lot less noise than the others, but the number of the medical touristic arrivals is close to those in Asian countries (Youngman, 2009). Three main questions arise regarding the statement: Firstly, how can medical tourism be defined in the case of Hungary? Secondly, what are the structure and volume of the medical touristic market of Hungary? Lastly, whether making less noise helps retaining competitiveness or whether other steps are needed? Due to the exploratory nature of the study, the qualitative case study methodology was chosen. To assure triangulation, the information was gained from the following sources: (1) secondary sources (studies, articles); (2) content analysis of the web pages of the service providers; and (3) open-structured interviews with experts from different areas (Hungarian Healthcare Ministry, research institutes, leader of international medical touristic facilitators, and private clinics).

\section{Defining Medical Tourism in Hungary}

It is particularly important to differentiate surgical tourism from therapeutic tourism in the pool of medical tourism in Hungary, as the latest is commonly known even in the touristic industry as medical tourism related to treatments based on healing or thermal water, and the surgical part of the product got less or hardly no common interest until the last year. The main reasons for this are that the culture of thermal water baths is nearly 2,000 years old and the country is one of the richest areas with medical and thermal water in the world. That is the reason why the commonly known idea of health tourism is nearly equal to thermal tourism. However, we can face the dynamic development of wellness tourism, the phenomenon usually far away from the international concept of holistic wellness. Thermal tourism was the main focus of the governmental subsidies and the national communication during the development of health tourism in the past 10 years. Nowadays, the importance of surgical tourism was realized, and some funds were opened in 2009 (mainly for municipalities) to develop infrastructure, and the issue got into the focus of the Hungarian National Touristic Office (HNTO) in the latest 
years, mainly in dental segment, particularly in Germany. In the surgical medical touristic market of Hungary, it is important to divide the market into private clinics and state hospitals, regarding the different significance and management issues of the areas. Summarizing the definitional questions, from the scope of the structure and volume, two different service segments are significant in Hungary: (1) therapeutic medical touristic market; and (2) surgical medical touristic market: (a) operated by private sector; and (b) operated by public sector.

\section{The Scope of the Medical Touristic Market and Implications}

Regarding the success factors of the overall touristic sector highlighted in Figure 1, the state of the Hungarian touristic sector seems to be good enough to assure the basis for medical tourism. Considering the latest results of Travel and Tourism Competitiveness Index (TTCI) (World Economic Forum [WEF], 2009), Hungary was in the first third part of the ranked 133 countries regarding the rest of the factors in question. The state of the airport infrastructure should be pointed out, as it got the lowest score of 3.0 (from 7.0). The poor score can be explained by the fact that there is only one significant international airport in Hungary, and the frequencies of the airlines were reduced in the latest years (affecting particularly badly the surgical touristic players).

Therapeutic medical touristic market. Hungary can be evaluated as a great power regarding the thermal and healing water resources, as it possesses nearly 1,300 thermal springs, among which 300 are used for bathing. The scope of the healing waters is uniquely wide and assures cure for orthopedic, rheumatologic, cardiologic, dermatologic, and gynecological diseases. The therapeutic touristic market generated a turnover of 147 million EUR in 2008 (ESKI, 2009). Though Hungary has a great tradition in therapeutic tourism, the question is whether the infrastructure of thermal baths and spa hotels can keep up with the newest trends demanding traditional therapies in a more holistic view of well-being. A shocking result of the researches of Techniker Krankenkasse (German health insurer) (2009) and Mezősi (2009) investigating the opinions of German travelers raises serious questions regarding this issue. The rest of tourists $(80 \%)$ were satisfied with the amenity services and leisure activities in Hungary, but only $50 \%$ of them were content with the therapeutic treatments and ca. $35 \%$ with the medical supervision.

In order to give a picture of the therapeutic touristic infrastructure, a content analysis was done. The random sample (every fifth of the sites) was chosen from the database of the HNTO (2009), containing 85 thermal baths, 52 spa hotels, and 10 spa hospitals. The analysis focuses on the features of the medical and wellness facilities of the service providers. All the analyzed thermal baths possess thermal pool (100\%), further on, balneo-fizio therapy is quite regular (45\%), but medical supervision is rare $(20 \%)$, while complementary wellness services appear at $45 \%$ of the baths, but alternative healing methods are missing. In the spa hotels, medical services, particularly rehabilitation of orthopedic, rheumatologic diseases, are common as well as healing water baths, balneo-fizio therapeutic treatments, and diagnostic sections, while clinical services appeared at $30 \%$ of the hotels. Average wellness services (e.g., sauna, pampering) are regular, while alternative methods (e.g., Ayurveda) are rare. The main orientation of the analyzed spa hospitals includes rehabilitation, angiology, gastroenterology, and gynecology. Summarizing the results, it can be said that the Hungarian therapeutic touristic infrastructure is well-developed to serve the mass medical tourism demanded by elderly patients. In order to meet the needs of the 50+ segment, innovation and up-to-date services, as well as well-defined atmosphere are needed, and serious specialization should be done to serve younger people with the need for lifestyle therapies, or cure for special diseases. Therapeutic tourism is one of the key issues of the Hungarian touristic development as well as the promotion with the aim of becoming the "Pannon Healing 
Power" of Europe according to the National Health Touristic Strategy (Országos Egészségturisztikai Fejlesztési Stratégia, OEFS) (The Ministry of Local Government and Regional Development Tourism, 2007). However, we have great comparative advantages based on natural resources, the location-based special, innovative treatments are missing, as well as the up-to-date holistic atmosphere of the spas. That is the reason why the strategy gives priority to product development, research and development (R\&D), and qualification (The Ministry of Local Government and Regional Development Tourism, 2007). Unique products could be developed in the area of thermal and healing water, medicinal plants, or the special area called hypo-therapy. This kind of innovative treatments could mean unique attractiveness or could be combined with the suitable surgical touristic service to give complex products.

Surgical medical touristic market. There is no exact statistic counting the number and the turnover of the players involved in the surgical medical touristic market, but according to the estimations of ESKI (2009), the private sector does the bulk of the turnover. First of all, the basic information and characteristics of the market will be described, followed by an analysis of the private and public sectors, based on the success factors of medical services (see Figure 1).

The turnover of the total market (private and public together) is estimated to be around 36-56 billion HUF (1 EUR $=265$ HUF), $90 \%$ of which is assured by private service providers. Nearly 300-400 thousand surgical tourists arrive at Hungary yearly, and around $50 \%-60 \%$ of them are cured at private clinics. Being Hungary a player in the surgical touristic market can be due to the hard and isolated work of the private service providers, who build the international reputation of the Hungarian clinics as a bottom-up process, but the public hospitals take a part in the surgical tourism as well. As having no proper statistics of the surgical touristic players, summarizing the main characteristics of the surgical market (see Table 1) is based on the estimation of the Hungarian Healthcare Research Institution (ESKI, 2009) and experts' interviews.

Table 3

The Main Characteristics of the Hungarian Surgical Touristic Market

\begin{tabular}{|l|l|l|l|}
\hline & Main product & Main source market & Player \\
\hline Private clinics & $\begin{array}{l}\text { Dentistry }(80 \%), \text { cosmetic and eye } \\
\text { surgeries, in-vitro fertilization } \\
\text { (IVF), and obesity surgery }\end{array}$ & A, CH, D, IR, Ro, DK, N, USA & $\begin{array}{l}\text { n.d. about 600-800 clinics, and } \\
\text { doctors in border-land, Budapest, and } \\
\text { spatowns }\end{array}$ \\
\hline Public clinics & $\begin{array}{l}\text { Gynecology, cancer, } \\
\text { ardio-vascular treatments, and eye } \\
\text { surgery }\end{array}$ & D, Ro, A, S, UA, USA & $\begin{array}{l}\text { n.d. hospitals in Budapest, } \\
\text { border-land, close to research } \\
\text { institutions }\end{array}$ \\
\hline
\end{tabular}

Notes. A = Austria; $\mathrm{CH}=$ Switzerland; D = Germany; IR = Ireland; Ro = Romania; DK = Denmark; $\mathrm{N}=$ Norway; $\mathrm{S}=\mathrm{Sweden}$; and $\mathrm{UA}=$ Ukraine.

Though the public and private players should be analyzed separately with regard to success and management factors, there are some mutual sources of comparative advantages, which give the basis for surgical tourism in Hungary:

(1) Cost advantage: The costs of medical treatments are definitely low in Hungary, due to low wages, compared with those in the developed countries: rest of the treatments (from heart bypass to spine surgery) cost just $5 \%-15 \%$ of the costs in the USA. The prices of the treatments are significantly (by $50 \%-60 \%$ ) lower than that in the USA, but the difference is great regarding the expenses in Germany, where eye surgery costs 2,782 USD (in Hungary, 846 USD) and facelift costs 9,126 USD (in Hungary, 4,881 EUR) (ESKI, 2009); 
(2) High-skilled staff: "Another thing that many may find surprising is that Hungarian surgeons are held to much stricter educational standards than those in the UK or US" (Medical Tourism Association, 2009, p. 1). Though the high skills of the doctors seem to be one of the most important enabling competencies of Hungary, shortcomings should be pointed out. The Hungarian public hospitals face a great volume of brain pipe because of low wages, the aging of the health professionals causing an average low foreign language skill level, as well as lack of service-oriented views among the public professionals. Widening surgical tourism could be a solution, as the Hungarian doctors working abroad could be attracted back, or unless while staying abroad, they could mean important market ties in the pre-travel as well as in the follow-up process. Education can hold market ties as well: Thousands of international students learn medicine in Hungary, and after returning home, they can be ambassadors of the Hungarian surgical tourism. These kinds of contacts are used by the private clinics where the high-level medicine, language, and management skills are given;

(3) Innovation/R\&D: The Hungarian medical science and research have world famous results in the area of orthopedics (backbone surgery), cardiology (invasive surgery), improvement of the disabled people (Petö method), or IVF (Kaáli method). However, these results are known in the circles of medicine and affected patients, with wider communication, these areas could serve the improvement of the image of the Hungarian medical professionals.

Surgical tourism in the private sector. Hungary got to the map of surgical tourism due to the private initiations, started by the dentists in the border-land towns, close to Austria in the 1990s, and dental tourism is still the most important product as well as trademark of the Hungarian surgical tourism. Since then, the example as well as the market know-how began to spread in the country, and hundreds of players launched isolated businesses and international marketing in different areas, without any cooperation or state subsidy. However, the individual initiations work well, the threat of the new competitors (Bulgaria and Rumania), and the aggressive market behavior of the older ones (the Czech Republic and Poland) ask for new solutions as well as governmental support. In order to get a picture of the market behavior of the private clinics, a content analysis was carried out. As there is no available statistic about the number of clinics involved in the surgical tourism, typing the keywords (private clinic, dental, cosmetic, eye surgery, and Hungary) in the Google maps seemed to be a good solution to find the individual service providers. Though problems arose with this solution, as from the hitting list of some hundreds, only 200 hits were shown, which should be handled as the basic of the sample, from which every fifth were analyzed in the dimension of transparency, accreditation, and seamless services. The evaluation of success factors in the private sphere based on the content analysis and experts' interviews is as follows:

(1) Transparency, which seems to be an issue to be developed: The statistics of the successful/unsuccessful cases appeared only at one service provider, the prices were missing at $25 \%$ of the clinics, as well as the own guarantee;

(2) Image: The Hungarian dental, cosmetic, and eye surgeries have a great reputation in the international market at which industrialized medical tourism could be built out;

(3) Accreditation: Neither of the Hungarian clinics possesses international accreditation, according to the list of the accreditation institutions (Joint Commission International (JCI), Tempos, and Australian Council on Healthcare Standards (ACHS)), and only $15 \%$ of the clinics analyzed have Technischen Uberwachungs Vereine (TÜV)/International Standardization Organization (ISO) accreditation, which means a disadvantage. According to the leader of the medical facilitator as well as an expert of the Healthcare Ministry, accreditation is essential 
for simple reasons: (a) It is a marketing tool serving comparison; (b) It is the basic requirement of public and the rest of the private insurance institutions; and (c) Without contracts with these institutions, the industrialized medical tourism cannot be built out. In the near future, a centralized qualification process will be started in the aim of mapping the market, assuring unified quality by recommendations, researching the satisfaction of the patients, as well as broadcasting information about patients' mobility (ESKI, 2009). However, this kind of process is essential, being the accreditation accepted by the target market of the service provider a crucial factor;

(4) Seamless services: The professional medical facilitators discovered the country in 2004, when Hungary joined the EU and started to carry out the seamless service in a great volume (Hungarian Association of Leading Dentistries [VMFE], 2009). The seamless service is carried out by the rest of the players in dentistry; what is more, the practice of organizing consulting possibilities in the mother country became the best practice in the market (Pollard, 2010). Other players, particularly in the cosmetic surgery, are in difficult situations, as complex diagnoses are needed, which cost a lot in the mother country, so they offer "fam-trips" to assure the first check-up and the personal contact with the doctors and the country at an affordable price. The follow-up process seems to be hard to solve: "It is really difficult, as the doctors in the mother country are willing to reject to give help to a returned medical tourist. The solution is to find a Hungarian doctor in the mother country or to take the patient back to Hungary" (interview with a medical facilitator). According to the content analysis, only $35 \%$ of the clinics analyzed promote supporting services (transfer and hostess), the complementary services (hotels and flights) appear at $52 \%$ of the clinics, while $40 \%$ of them have international contact (facilitator, consulting possibility in the source country), and only $10 \%$ of them promote their contracts with international insurances. Regarding these results, it can be said that the greater or first-mover players of the market started the seamless process, while the smaller or newer players in the majority should realize the importance of that;

(5) Insurance: According to the experts' interviews, there are several clinics in contract with Italian as well as German insurance institutions. There are good practices of the private clinics to handle the patients' mobility. According to the leader of a private clinic, the process is not easy but can be managed. Firstly, they build contacts with the general practitioners (GPs) in the mother country who make the administration of the authorization process of the public health insurance company. The patients are cured in Hungary with the permission of the insurance institutions, and the bill is made out for the institutions, and to make the payment sure, the clinics make insurance for recovering the debt. This extra way of security works in all cases, when the public insurance company delays the payment;

(6) Innovation: Working with the up-to-date technology is crucial in most competitive areas (dentistry, cosmetic, and eye surgeries), and according to the experts' opinions, the Hungarian players invest in the newest know-how without sparing pains. Alternative healing methods are important areas of innovation. Medical herbal treatments have already been used in the dental surgery, but healing water could serve for plastic surgery as well as gynecology, if suitable treatments, with suitable infrastructure, would be assured by the spas. There is a good example of cooperation between spa hotels and private clinics: In Budapest as well as in the border-land towns, luxurious hotels with high-quality spas give locations for surgeries and rehabilitation.

Surgical tourism in the public sector. Some public hospitals (no accurate datum) started to be involved in the surgical tourism, though the rest of the leaders of the public clinics find tourism a way out of their generally 
difficult financial situations. In Hungary, the rest of the hospitals are owned by municipalities or the state, and the Hungarian healthcare systems are financed by centralized public insurance fees and taxes. However, the system suffers from deficit in almost every year. It is important to highlight that one of the major problems, beyond the lack of financial resources, is the ineffective structure and operation of the hospitals. In 2007, a major structural reform started, and the overcapacity of the state hospital was partly reduced by cutting the number of acute beds and increasing the volume of chronic beds. However, the reform was needed. The time pressure of the process did not allow enough scope for finding the optimal volume as well as financing (OECD, 2008). That is the reason why there is free capacity at different treatments (e.g., orthopedics, heart surgery) without enough hospital beds. This unutilized capacity could be used by the medical tourists, if proper amenity service is built out and could be the source for extra turnover for the hospitals as well as for the staff. It is essential to have a governmental decision regarding developing surgical tourism in the public sphere. The healthcare system of Hungary is under reformation, and newer steps could be expected regarding enhancing the effectiveness and the quality. The question is whether the state, as the main owner, supports the idea of surgical tourism and starts to pump EU subsidies to major hospitals, with a focus on surgical tourism. The state of the public hospitals regarding the success factors of medical tourism is as follows:

(1) Transparency: There are serious problems regarding transparency, even it is difficult to define how many individually financed treatments were made or how many doctors made diagnostic analyses for their own private patients in the hospital. It is highly significant to make a transparent solution; otherwise, there could be a threat for having waiting lists for the residents, when surgical tourism starts to boom. The issue of transparency arises in the area of statistics, considering the success of the treatments as well. The Hungarian public health insurance started to make statistics about the failures to know which point of the healing process should be improved, but they are not public and we do not have proper information about the amenity services provided by the hospitals;

(2) Image: According to the leader of a private clinic, "However, there are great results in orthopedics, cardiology the good skills of our doctors is not communicated widely. That is the reason why Hungarian healthcare is not on the medical map, it is not the first destination, what came to the mind of an ill person searching for cure. It is another question that there areas, where prices, and the word of mouth have their effects";

(3) Accreditation: As well as in the private sector, accreditation seems to be essential (or even more essential) in the public sector. That could be the starting point to widen the contracts with foreign public and private insurance companies;

(4) Seamless services and insurance: Though we have little information about the market ties of the public hospitals, the experts' interviews show that the international facilitators reached the public hospitals as well. The foreign public and private insurance companies are also involved in the process. The basic problems are the low quality of the amenity services and the lack of service-oriented views of the health professionals. If the government gives its vote for surgical tourism in the public sphere, the problems could be remedied by the partner-hospital model (isolated wing of hospitals for medical tourism, using the same infrastructure of the public hospital (ESKI, 2009)), or by cooperation with hotels;

(5) Innovation: The medical infrastructure of the rest of the hospitals is up-to-date enough to serve surgical tourism, but there are serious shortcomings regarding the amenity facilities detailed above. 


\section{Conclusions}

Hungary got to the map of worldwide medical tourism as a "Happy Dent" destination, since $80 \%$ of the treatments in the framework of surgical tourism refer to dentistry. Other areas like cosmetic and eye surgeries as well as gynecology, cancer, and cardio-vascular treatments provided by the public hospitals are in demand. Even the country has world famous results in orthopedics (backbone surgery), cardiology (invasive surgery), improvement of the disabled people (Petö method), or IVF (Kaáli method), all the knowledge has not been used out, because there is a lack of clinical capacity in the area or because there is a lack of marketing communication. Regarding the development phases of the medical tourism, the Hungarian service providers are at the stage of price advantage segment. Due to the permanent innovation of the private clinics, steps are taken to the next stage, which can be called "medium category with permanent patient flow and professional market behavior", while the world famous results could hold the possibility of getting to the premium category based on high-level know-how. In order to reach these stages, the following steps are recommended.

\section{Stage of Medium Category With Permanent Patient Flow and Professional Market Behavior}

Efforts are made in the area of dental, cosmetic, and eye surgeries for assuring permanent up-to-date quality as well as seamless, professional services. In order to have industrialized medical tourism and permanent patients flow, the best practice of seamless services and crucial solutions (e.g., pre-travel, follow-up services, travel insurance) should be spread, as well as joining the accreditation systems of the target markets. IFCs play a great role in this area by raising awareness and controlling the quality. Cooperation with the touristic sector and getting the well-deserved attention in the national touristic promotion of health tourism as well as in the development fund are essentials. The public sector faces several challenging questions detailed above, where the decision of the government to support the surgical tourism seems to be vital. Without governmental support, the model of "partner-hospital" cannot be carried out, but the surgical tourism can be increased with the help of hospitals and assistance services, in the area of outpatient surgery and rehabilitation. Differentiating strategy is important regarding the sharpening competition, and using traditional, national healing methods seems to be a good example (e.g., in Asia). The cooperation with the therapeutic touristic service providers could be a solution, in order to make specialized, high-quality methods and products based on healing water and medicinal plants.

\section{Stage of Premium Category Based on High-Level Know-How}

The areas of the distinguished results of the Hungarian medical research assure the possibility of getting in the circle of the "bests" in the medical touristic market. It is important to highlight that the rest of the results are reached in international cooperation or thought to foreign physicians to spread the knowledge of healing. This means that the know-how spreads quickly and eliminates the source of the competitiveness. From this perspective, the medical and pharmaceutical research institutions have a crucial role, to keep moving the wheels of innovation with new results. Based on the nowadays results, in the area of the unique methods detailed above, the actual limits of the infrastructural capacity should be lifted. It could happen even with the help of the private sector, and a high-level price, complex niche-product should be built out. All the areas in question can have rehabilitation, lifestyle treatments based on the therapeutic touristic services, which could add the extra possibility of differentiation. 


\section{References}

American Medical Association [AMA]. (2008). AMA guidelines for patients going overseas for care. Retrieved from http://www.ama-assn.org/amednews/2008/07/07/prse0707.htm

Biomedme. (2009). Medical tourism in Middle East: A two way strategy. Retrieved from $\mathrm{http}: / /$ biomedme.com/general/medical-tourism-in-middle-east-a-two-way-strategy_4385.html

Connell, J. (2012). Contemporary medical tourism: Conceptualisation, culture, and commodification. Tourism Management, 34, $1-13$.

Cook, P. S., Kendall, G., Michael, M., \& Brown, N. (2013). Medical tourism, xenotourism, and client expectations: Between bioscience and responsibilisation. In C. M. Hall (Ed.), Medical tourism: The ethics, regulation, and marketing of health mobility (pp. 61-74). London: Routledge.

Crompton, S. (2008). Is medical tourism worth the risk? Retrieved from http://www.timesonline.co.uk/tol/life_and_style/health/article4962341.ece

Deloitte. (2009). Medical tourism: Update and implications. Retrieved from http://www.deloitte.com/assets/Dcom-Greece/Local\%20Assets/Documents/Attachments/Health/Medical_tourism09.pdf

Hall, C. M. (2013). Medical tourism: The ethics, regulation, and marketing of health mobility (pp. 61-74). London: Routledge.

Harryono, M., Huang, Y., Miyazawa, K., \& Sethaput, V. (2006). Thailand medical tourism cluster. Retrieved from http://www.isc.hbs.edu/econ-student_projects.htm

Health Care Research Centre [ESKI]. (2009). Az orvosi szolgáltatásokra alapuló egészségturizmus tendenciái (Health tourism, medical services, based on the trends). Retrieved from http://www.eski.hu/new3/gyogyturizmus/zip_doc_2009/egeszsegturizmus.pdf

Hungarian Association of Leading Dentistries [VMFE]. (2009). How it was started? Retrieved from http://www.eski.hu/new3/publ/.../2009/.../Tolnai\%20hogyan\%20kezdodott.pps

Hungarian National Tourist Office [HNTO]. (2009). Spa and wellness database. Retrieved from http://itthon.hu/spas-wellness

Johnson, B. (2010). The role of international hospital accreditation in medical tourism. Retrieved from http://itthon.hu/spas-wellnesshttp://www.imtj.com/articles/2010/hospital-accreditation-30040/?source=email\&campaign=imt j_news_100218

McKinsey. (2008). Mapping the market for medical travel. Retrieved from https://www.mckinseyquarterly.com/Mapping_the_market_for_travel_2134

Medical Tourism Association. (2009). Information on European medical tourism in different European countries. Retrieved from http://www.europeanmedicaltourismcongress.com/

Medical Tourism Association. (2013). Medical tourism FAQ's. Retrieved from http://www.medicaltourismassociation.com/en/medical-tourism-faq-s.html

Mezősi, C. (2009). Nemzetközi kitekintés. Lehetöségek az orvos turizmus területén-Hogyan gazdálkodunk az adottságokkal (International outlook. Possibilities in the market of surgical medical tourism-How we deal with our resources)? Retrieved from http://www.turizmus.com/eloadas/MezosiCsilla.pdf

Organization for Economic Cooperation and Development [OECD]. (2008). Healthcare reform: Improving efficiency and quality of care. In Reforms for stability and sustainable growth: An OECD perspective on Hungary (Chapter 3). Retrieved from http://www.oecd.org/dataoecd/2/9/40473940.pdf

Organization for Economic Cooperation and Development [OECD]. (2009). Health at a glance 2009: OECD indicators. Retrieved from http://www.oecdilibrary.org/oecd/sites/health_glance-2009-en/07/08/index.html;jsessionid=28094pdo61euf. delta? content Type $=$ \&itemId $=/$ content $/$ serial $/ 19991312$

Pollard, K. (2010). The outlook of medical tourism 2010. Retrieved from http://treatmentabroad.blogspot.com/2010/01/outlook-for-medical-tourism-in-2010.html

Smith, M. K., \& Puczkó, L. (2009). Health and wellness tourism. Oxford: Butterworth Heinemann.

Techniker Krankenkasse. (2009). Germany: German medical tourism on the increase? Retrieved from http://www.treatmentabroad.com/medical-tourism/news/?EntryId82=136796

The Ministry of Local Government and Regional Development Tourism. (2007). Országos Egészségturisztikai Fejlesztési Stratégia (National health touristic strategy). Aquaprofit Rt..

World Economic Forum [WEF]. (2009). The travel \& tourism competitiveness report 2009. Retrieved from http://www.weforum.org/documents/TTCR09/index.html

Youngman, I. (2009). Medical tourism statistics: Why McKinsey has got it wrong? Retrieved from http://www.imtj.com/articles/2009/mckinsey-wrong-medical-travel/ 
Appendix A: The Characteristics of the Main (or Selected) Medical Touristic Destinations

\begin{tabular}{|c|c|c|c|c|c|}
\hline Country & Main area & Main characteristic & Price (USD) & Accreditation & Overall message \\
\hline Thailand & $\begin{array}{l}\text { General surgery, } \\
\text { cardiac surgery, } \\
\text { cosmetic surgery, } \\
\text { dentistry, and } \\
\text { orthopedics }\end{array}$ & $\begin{array}{l}\text { Some first-mover, } \\
\text { prominent hospitals } \\
\text { with strong } \\
\text { communication, } \\
\text { strong state subsidies, } \\
\text { Thai treatments, } \\
\text { rehabilitation, and low } \\
\text { prices }\end{array}$ & $\begin{array}{l}\text { (1) Dental implant } \\
\text { (1,600 USD); } \\
\text { (2) Facelift } \\
\text { (2,400 USD). }\end{array}$ & $\begin{array}{l}\text { (1) JCI: } 9 \text { hospitals; } \\
\text { (2) Treatment abroad: } \\
5 \text { hospitals. }\end{array}$ & $\begin{array}{l}\text { High quality, low } \\
\text { price, exotic travel, } \\
\text { and great experience } \\
\text { in medical travel } \\
\text { (image made by the } \\
\text { service suppliers and } \\
\text { facilitators) }\end{array}$ \\
\hline Singapore & $\begin{array}{l}\text { General surgery, } \\
\text { cardiac surgery, } \\
\text { ophthalmology, } \\
\text { orthopedics, } \\
\text { gynecology, and } \\
\text { urology }\end{array}$ & $\begin{array}{l}\text { Strong governmental } \\
\text { support, national } \\
\text { communication, low } \\
\text { prices, and traditional } \\
\text { Chinese medicine }\end{array}$ & $\begin{array}{l}\text { (1) Dental implant } \\
\text { (1,180 USD); } \\
\text { (2) Facelift } \\
\text { (2,700 USD). }\end{array}$ & $\begin{array}{l}\text { (1) JCI: } 16 \text { hospitals; } \\
\text { (2) Treatment abroad } \\
\text { (n.d.). }\end{array}$ & $\begin{array}{l}\text { "Peace of mind when } \\
\text { health really } \\
\text { matters"-high } \\
\text { quality, low prices, } \\
\text { transparent national } \\
\text { facilitator system, and } \\
\text { strong communication }\end{array}$ \\
\hline India & $\begin{array}{l}\text { Cardiac surgery, } \\
\text { orthopedics, } \\
\text { ophthalmology, and } \\
\text { alternative medicine }\end{array}$ & $\begin{array}{l}\text { Some prominent } \\
\text { hospitals, strong } \\
\text { market contacts, } \\
\text { governmental support, } \\
\text { differentiation } \\
\text { (holistic concept } \\
\text { (alternative } \\
\text { methods)), and extra } \\
\text { low prices }\end{array}$ & $\begin{array}{l}\text { (1) Dental implant } \\
\text { (500 USD); } \\
\text { (2) Facelift } \\
\text { (2,700 USD). }\end{array}$ & $\begin{array}{l}\text { (1) JCI: } 16 \text { hospitals; } \\
\text { (2) Treatment abroad: } \\
6 \text { hospitals. }\end{array}$ & $\begin{array}{l}\text { "The global } \\
\text { healthcare } \\
\text { destination"_- holistic } \\
\text { view: Western } \\
\text { medicine and } \\
\text { traditional Indian } \\
\text { treatments (Ayurveda } \\
\text { and Yoga), } \\
\text { governmental support, } \\
\text { and medical tourism } \\
\text { on the official } \\
\text { national touristic site }\end{array}$ \\
\hline USA & $\begin{array}{l}\text { Rare, complex } \\
\text { illnesses, treatment of } \\
\text { cancer, cardiology, } \\
\text { neurotic treatments, } \\
\text { and general surgery }\end{array}$ & $\begin{array}{l}\text { Famous clinics, the } \\
\text { highest technology } \\
\text { and skills, and } \\
\text { continuous R\&D }\end{array}$ & $\begin{array}{l}\text { (1) Dental implant } \\
\text { (2,800 USD); } \\
\text { (2) Facelift } \\
\text { (14,500 USD). }\end{array}$ & $\begin{array}{l}\text { (1) JCI: n.d. hospitals; } \\
\text { (2) Treatment abroad: } \\
3 \text { hospitals. }\end{array}$ & $\begin{array}{l}\text { Leading surgeons and } \\
\text { hospitals in the world } \\
\text { with the most } \\
\text { up-to-date R\&D } \\
\text { results (image built by } \\
\text { market players) }\end{array}$ \\
\hline Belgium & $\begin{array}{l}\text { Cardiology, cosmetic } \\
\text { surgery, } \\
\text { transplantation, } \\
\text { dentistry, and fertility } \\
\text { treatments }\end{array}$ & $\begin{array}{l}\text { Close to main markets } \\
\text { (UK, Netherland), } \\
\text { strong market } \\
\text { contacts, high quality, } \\
\text { low(er) prices, and } \\
\text { opened society }\end{array}$ & $\begin{array}{l}\text { (1) Dental implant } \\
\text { (1,000 USD); } \\
\text { (2) Facelift } \\
(3,524 \text { USD). }\end{array}$ & $\begin{array}{l}\text { (1) JCI: n.d. hospitals; } \\
\text { (2) Treatment abroad: } \\
12 \text { hospitals. }\end{array}$ & $\begin{array}{l}\text { Modernity, high } \\
\text { quality, and cost } \\
\text { efficiency (image } \\
\text { built by market } \\
\text { players) }\end{array}$ \\
\hline Germany & $\begin{array}{l}\text { Wide variety for } \\
\text { surgery: from } \\
\text { cosmetic to spinal, } \\
\text { cardiology }\end{array}$ & $\begin{array}{l}\text { Prominent hospitals in } \\
\text { famous destinations, } \\
\text { advanced technology, } \\
\text { R\&D, high skills, and } \\
\text { rehabilitation (spas } \\
\text { and health resorts) }\end{array}$ & $\begin{array}{l}\text { (1) Dental implant } \\
\text { (1,188 USD); } \\
\text { (2) Facelift } \\
\text { (9,126 USD). }\end{array}$ & $\begin{array}{l}\text { (1) JCI: } 5 \text { hospitals; } \\
\text { (2) Treatment abroad: } \\
5 \text { hospitals. }\end{array}$ & $\begin{array}{l}\text { Excellent reputation, } \\
\text { high skills, high-tech, } \\
\text { and rehabilitation } \\
\text { (image built by } \\
\text { market players) }\end{array}$ \\
\hline Spain & $\begin{array}{l}\text { Gastric bypass, } \\
\text { cosmetic surgery, } \\
\text { dentistry, orthopedics, } \\
\text { and IVF }\end{array}$ & $\begin{array}{l}\text { Ranked as the 7th for } \\
\text { highest-quality } \\
\text { healthcare in the EU } \\
\text { (World Health } \\
\text { Organization), famous } \\
\text { holiday destination, } \\
\text { cheap touristic } \\
\text { infrastructure, long } \\
\text { stay, returning, and } \\
\text { close to main markets } \\
\text { (UK, Germany, and } \\
\text { Italy) }\end{array}$ & $\begin{array}{l}\text { (1) Dental implant } \\
\text { (1,288 USD); } \\
\text { (2) Facelift } \\
\text { (7,198 USD). }\end{array}$ & $\begin{array}{l}\text { (1) JCI: } 17 \text { hospitals; } \\
\text { (2) Treatment abroad: } \\
\text { over } 40 \text { hospitals. }\end{array}$ & $\begin{array}{l}\text { Medical hub of } \\
\text { Europe, high quality, } \\
\text { and low cost (image } \\
\text { built by market } \\
\text { players) }\end{array}$ \\
\hline
\end{tabular}


(Appendix A continued)

\begin{tabular}{|c|c|c|c|c|c|}
\hline Country & Main area & Main characteristic & Price (USD) & Accreditation & Overall message \\
\hline Cyprus & $\begin{array}{l}\text { Cosmetic, dental } \\
\text { surgery, orthopedics, } \\
\text { cardiology, and IVF }\end{array}$ & $\begin{array}{l}\text { High skills, } \\
\text { international training } \\
\text { for doctors, high-tech } \\
\text { private centers, and } \\
\text { prominent vacation } \\
\text { destinations }\end{array}$ & $\begin{array}{l}\text { (1) Dental implant } \\
\text { (1,671 USD); } \\
\text { (2) Facelift } \\
\text { (5,343 USD). }\end{array}$ & $\begin{array}{l}\text { (1) JCI: } 4 \text { hospitals; } \\
\text { (2) Treatment abroad: } \\
19 \text { hospitals. }\end{array}$ & $\begin{array}{l}\text { "Treasure your health } \\
\text { in Cyprus"-complex } \\
\text { health and vacation } \\
\text { experience, } \\
\text { governmental support, } \\
\text { and medical tourism } \\
\text { on the official } \\
\text { national touristic site }\end{array}$ \\
\hline $\begin{array}{l}\text { The Czech } \\
\text { Republic }\end{array}$ & $\begin{array}{l}\text { Dental, cosmetic } \\
\text { surgery, IVF, and } \\
\text { rehabilitation }\end{array}$ & $\begin{array}{l}\text { High quality, low } \\
\text { prices, close to main } \\
\text { markets (Germany, } \\
\text { Austria), and famous } \\
\text { spas and towns }\end{array}$ & $\begin{array}{l}\text { (1) Dental implant } \\
\text { (1,046 USD); } \\
\text { (2) Facelift } \\
\text { (4,051 USD). }\end{array}$ & $\begin{array}{l}\text { (1) JCI: } 4 \text { hospitals; } \\
\text { (2) Treatment abroad: } \\
3 \text { hospitals. }\end{array}$ & $\begin{array}{l}\text { High standards, low } \\
\text { prices, and great } \\
\text { natural resources } \\
\text { (image built by } \\
\text { market players) }\end{array}$ \\
\hline Poland & $\begin{array}{l}\text { Dentistry, cosmetic } \\
\text { surgery, cardiology, } \\
\text { ophthalmology, and } \\
\text { neurology }\end{array}$ & $\begin{array}{l}\text { Close to main markets } \\
\text { (Germany, Russia, } \\
\text { and North Europe), } \\
\text { international training } \\
\text { for doctors, high-tech } \\
\text { private centers, and } \\
\text { success in innovation }\end{array}$ & $\begin{array}{l}\text { (1) Dental implant } \\
\text { (805 USD); } \\
\text { (2) Facelift } \\
\text { (3,980 USD). }\end{array}$ & $\begin{array}{l}\text { (1) JCI: } 0 \text {; } \\
\text { (2) Treatment abroad: } \\
8 \text { hospitals. }\end{array}$ & $\begin{array}{l}\text { High quality with } \\
\text { international } \\
\text { experience, } \\
\text { innovation, and low } \\
\text { prices (image built by } \\
\text { market players) }\end{array}$ \\
\hline Croatia & $\begin{array}{l}\text { Dental and cosmetic } \\
\text { surgery }\end{array}$ & $\begin{array}{l}\text { Low prices, high } \\
\text { skills, starting } \\
\text { networking, and } \\
\text { traditional image in } \\
\text { vacation tourism } \\
\end{array}$ & $\begin{array}{l}\text { (1) Dental implant } \\
\text { (975 USD); } \\
\text { (2) Facelift } \\
\text { (4,813 USD). }\end{array}$ & $\begin{array}{l}\text { (1) JCI: } 0 \text {; } \\
\text { (2) Treatment abroad: } \\
15 \text { hospitals. }\end{array}$ & $\begin{array}{l}\text { Complex experience } \\
\text { and low prices }\end{array}$ \\
\hline Bulgaria & $\begin{array}{l}\text { Dental, cosmetic } \\
\text { surgery, lifestyle } \\
\text { treatments, and IVF }\end{array}$ & $\begin{array}{l}\text { Low cost, some } \\
\text { high-quality centers, } \\
\text { rest is under } \\
\text { construction, and spas } \\
\text { for rehabilitation }\end{array}$ & $\begin{array}{l}\text { (1) Dental implant } \\
\text { (1,166 USD); } \\
\text { (2) Facelift } \\
\text { (2,659 USD). }\end{array}$ & $\begin{array}{l}\text { (1) JCI: } 0 \text {; } \\
\text { (2) Treatment abroad: } \\
0 .\end{array}$ & $\begin{array}{l}\text { complex experience } \\
\text { and low prices }\end{array}$ \\
\hline Hungary & $\begin{array}{l}\text { Dental, cosmetic } \\
\text { surgery, orthopedics, } \\
\text { and ophthalmology }\end{array}$ & $\begin{array}{l}\text { High-quality centers, } \\
\text { highly-skilled staff with } \\
\text { international } \\
\text { experience, first-mover } \\
\text { hubs in Western } \\
\text { Hungary, and } \\
\text { unexploited innovations } \\
\text { in cardiology }\end{array}$ & $\begin{array}{l}\text { (1) Dental implant } \\
\text { (882 USD); } \\
\text { (2) Facelift } \\
\text { (4,885 USD). }\end{array}$ & $\begin{array}{l}\text { (1) JCI: } 0 \text {; } \\
\text { (2) Treatment abroad: } \\
28 \text { hospitals. }\end{array}$ & $\begin{array}{l}\text { "“Happy Dent”- high } \\
\text { quality, low prices, } \\
\text { complex experience } \\
\text { (image built by } \\
\text { market players), and } \\
\text { governmental support } \\
\text { recently started }\end{array}$ \\
\hline
\end{tabular}

Appendix B: The Characteristics of the Main Source Markets

\begin{tabular}{|l|l|l|l|l|}
\hline Country & Main motivation & Popular treatment & Popular destination & $\begin{array}{l}\text { No. of outbound tourist } \\
\text { arrivals (2008) }\end{array}$ \\
\hline USA & $\begin{array}{l}\text { Price sensitiveness and } \\
\text { complex treatments and } \\
\text { holiday }\end{array}$ & $\begin{array}{l}\text { General surgery, cancer } \\
\text { treatment, orthopedics, heart } \\
\text { bypass, and cosmetic surgery }\end{array}$ & $\begin{array}{l}\text { Asia, Latin America, } \\
\text { Middle East, and USA }\end{array}$ & Ca. 540 ths. \\
\hline Middle East & Highest-level technology & $\begin{array}{l}\text { Heart surgery, cancer } \\
\text { treatment, orthopedics, and } \\
\text { detox programs }\end{array}$ & $\begin{array}{l}\text { North America, Asia, } \\
\text { and Europe }\end{array}$ & $\begin{array}{l}\text { No overall estimation: United } \\
\text { Arab Emirates (UAE) 100 } \\
\text { ths., Saudi Arabia 200 ths. }\end{array}$ \\
\hline Germany & $\begin{array}{l}\text { Motivation of public } \\
\text { insurance, price sensitiveness } \\
\text { at elective treatments }\end{array}$ & $\begin{array}{l}\text { Dental treatments, } \\
\text { orthopedics, and cosmetic } \\
\text { and eye surgeries }\end{array}$ & $\begin{array}{l}\text { The Czech Republic, } \\
\text { Hungary, and Poland }\end{array}$ & Ca. 272 ths. \\
\hline UK & $\begin{array}{l}\text { Motivation of public } \\
\text { insurance, price sensitiveness } \\
\text { at elective treatments, hospital } \\
\text { infection, and complex holiday }\end{array}$ & $\begin{array}{l}\text { Dental, cosmetic, and } \\
\text { orthopedic surgeries and } \\
\text { fertility treatments }\end{array}$ & $\begin{array}{l}\text { Belgium, Spain, India, } \\
\text { Hungary, and Cyprus }\end{array}$ & Ca. 75 ths. \\
\hline
\end{tabular}

Note. Source: Pollard (2010), Deliotte (2009), McKinsey (2008), Techniker Krankenkasse (2009), Crompton (2008), and Biomedme (2009). 